\title{
Influence of palm sugar to the functional properties of bekasam hydrolysate
}

\author{
${ }^{1}$ Sri Anggrahini, ${ }^{1}$ Setyaningsih, W., ${ }^{1}$ Ningrum, A., ${ }^{2}$ Anto, and ${ }^{3}$ Agustiari, N.M. \\ ${ }^{1}$ Department of Food Science and Agricultural Product Technology, Faculty of Agricultural Technology, \\ Gadjah Mada University, Jl. Flora No.1 Bulaksumur, Yogyakarta 55281 \\ ${ }^{2}$ Ichsan University, Gorontalo, Indonesia \\ ${ }^{3}$ Program Study of Food Science and Technology, Department of Food Science and Agricultural Product \\ Technology, Faculty of Agricultural Technology, Gadjah Mada University, Jl. Flora No.1 Bulaksumur, \\ Yogyakarta 55281
}

\begin{abstract}
Article history:
January 2019 2019

Keywords:

ACE-inhibitor,

Oci fish,

Bekasam,

Trypsin,

Hydrolysis
\end{abstract}

Received: 13 November 2018

Received in revised form: 7

Accepted: 12 January 2019

Available Online: 28 January

DOI:

https://doi.org/10.26656/fr.2017.3(3).303

\begin{abstract}
Hypertension is one of the major global health issues worldwide. One of the methods can be used to treat this disease is by inhibiting the activity of angiotensin converting enzyme, an enzyme that controls the regulation of arterial blood pressure and cardiac output. Bekasam is one of the traditional fermented food made from freshwater fish (oci, Rastreliger kanaguria) with the addition of carbohydrate sources (variation concentration of palm sugar i.e. $10 \% ; 20 \%$; and $30 \%$ ). The objective of this research was to investigate the effect of palm sugar concentration to the ACE inhibitor activity of bekasam after digestive enzyme degradation by trypsin. Hydrolysis process was evaluated by determination of the concentration of soluble protein and the degree of hydrolysis (DH) after treatment and the ACE-inhibitory (ACEI) effect was determined by spectrophotometry method. Compared to the control without trypsin treatment $(5.00 \pm 0.10 \mathrm{mg} / \mathrm{ml})$, the concentration of soluble protein $(\mathrm{mg} / \mathrm{ml})$ of bekasam was increased after trypsin hydrolysis to $16.57 \pm 0.55$ at $10 \%$ of added palm sugar and then decreased to $15.38 \pm 0.18$ and $10.85 \pm 0.28$, at 20 and $30 \%$ of added palm sugar respectively. The degree of hydrolysis was $21.3 \pm 0.3 \%, 19.7 \pm 0.5 \%$ and $15.3 \pm 0.4 \%$, for 10 , 20 and $30 \%$ of palm sugar, respectively. The ACE-inhibitory activity was $87.39 \pm 0.01$, $84.52 \pm 0.84$, and $77.68 \pm 0.63 \%$, for 10,20 and $30 \%$ of added palm sugar, respectively. The results showed that the concentration of palm sugar affects the soluble protein content, degree of hydrolysis and ACEI activity after trypsin hydrolysis with the optimum sugar concentration was $10 \%$.
\end{abstract}

\section{Introduction}

Hypertension is one of the major global health issues, owing to its chronic nature, wide prevalence and linkage with increased mortality and morbidity which affects approximately 16 to $37 \%$ of the global population (Poulter et al., 2015). Long term hypertension is one of the major risk factors and clinical manifestations of arteriosclerosis, cardiovascular diseases, strokes, heart failures, and chronic renal diseases (Bakris et al., 2014; Lackland and Weber, 2015).

Angiotensin-converting enzyme (ACE, EC 3.4.15.1) is a glycoprotein with carbohydrate moiety composed of mannose, galactose, fructose, $\mathrm{N}$-acetylneuraminic acid, and N-acetyl-glucosamine (Murray and Fitzgerald, 2007). ACE, found mainly in the capillaries of the lungs, is a key enzyme of the renin-angiotensin system (RAS) which is known as a cascade that controls the regulation of arterial blood pressure and cardiac output. This enzyme indirectly elevates the blood pressure by constricting the blood vessels. Therefore, one way to treat cardiovascular diseases is to inhibit the activity of ACE.

Many peptides derived from food proteins have been recommended to be Angiotensin-converting enzyme (ACE) inhibitors. Fish, as a source for food proteins, can be utilized as an ideal starting material for the production of novel ACE-inhibitory peptides. Annually, a large amount of fish is caught like as animal protein source and raw material in food industries. The abundance of the fish requires some ways for preservation, such as by fermentation. In Indonesia, fish fermentation method 
produced a well-known product called bekasam. Several fermented products use lactic acid bacteria (LAB) which has probiotic potential with beneficial effects on human health.

Enzymatic hydrolysis is a widely used method to release ACE-inhibitory peptides from fish proteins. The effectiveness of this method to generate specific peptide fragments with inhibitory activity mainly depends on the proteolytic enzyme used, hydrolysis conditions and the degree of hydrolysis (DH) achieved. A variety of enzymes including commercial proteases and proteases of microbial origin have been reported to produce ACEinhibitory peptides from various fish proteins.

There are different methods to obtain ACEinhibitory peptides from fish. The peptides can be extracted from fish proteins by using solvents and/or proteolytic enzymes (Chiang et al., 2006; HernandezLedesma et al., 2011; Thewissen et al., 2011). Several different proteolytic enzymes were reported to hydrolyze proteins such as alcalase, flavourzyme, thermolysin, trypsin, chymotrypsin, pepsin, papain, neutrase, bacterial and fungal proteases (Van der Ven et al., 2002; Chiang et al., 2006; Thewissen et al., 2011; Gu and $\mathrm{Wu}, 2013$ ). Thewissen et al. (2011) extracted peptides with $70 \%$ ethanol and extracts were hydrolysed with trypsin, ficin, or thermolysin. Liepke et al. (2001) produced ACEinhibitory peptides with hydrolysis protein via digestive enzymes such as pepsin, trypsin, or chymotrypsin. Pepsin, trypsin and $\alpha$-chymotrypsin are other important enzymes that have been utilized in the gastrointestinal simulation of peptide digestion (García-Tejedor et al., 2014; Iwaniak et al., 2014; Maestri et al., 2015). Pepsin has broad cleavage specificity with a preference for peptides containing linkages with aromatic or carboxylic 1-amino acids. It preferentially cleaves $\mathrm{C}$-terminal to $\mathrm{Phe}$ and Leu, which are important amino acids for the ACEinhibitory capacity of peptides (Murray and Fitzgerald, 2007; Sornwatana et al., 2015). Trypsin, on the other hand, cleaves the peptide after Lys or Arg. (Kim et al., 1999).

In some studies, the combination of enzymes was used to increase the level of potential ACE-inhibitory peptides due to enzyme specificity (Majumder and $\mathrm{Wu}$, 2010; Ambigaipalan et al., 2015). Indeed, pepsin, $\alpha$ chymotrypsin and trypsin were combined to simulate the gastrointestinal digestion of food proteins in humans (Guang and Phillips, 2009; Jimsheena and Gowda, 2011; $\mathrm{Gu}$ and $\mathrm{Wu}, 2013$ ). Furthermore, a combination of two or more enzymes may show higher ACE-inhibitory activity than single enzymatic treatment.

ACE-inhibitory peptides can be obtained through fermentation using cultures with proteolytic activities
(Hayes et al., 2007). Lactic acid bacteria (LAB) are generally used as a starter culture for ACE-inhibitory peptide fermentation (Hayes et al., 2007; Rizzello et al., 2008; Jakubczyk, 2013; Nejati et al., 2013; Shu et al., 2015). However, studies showed that microorganisms other than LAB such as Bacillus spp. (Lee et al., 2015; Moayedi et al., 2016), Staphylococcus vitulus (Fernández, et al., 2016), Saccharomyces cerevisiae (Vermeirssen et al., 2003; Murray and Fitzgerald, 2007; Jakubczyk et al., 2013), Debaryomyces hansenii (GarcíaTejedor, 2014), Mucor spp. (Hang and Zhao, 2012) and Aspergillus spp. (Wang et al., 2008) also can be used as Inoculum. Type of inoculum, fermentation conditions and inoculum levels play important roles in ACEinhibitory peptide production (Jakubczyk et al., 2013; Shu et al., 2015; Fernández et al., 2016).

Some synthetic inhibitors of ACE, such as captopril andenalapril, have proved to be useful as antihypertensive drugs (Ondetti et al., 1977; Astawan et al., 1995). However, synthetic inhibitors of ACEI have side effects, such as cough and angioneurotic oedema. Recently, food scientists are developing new angiotensinI converting enzyme (ACE) inhibitors from natural foods (Murray and Fitzgerald, 2007), with the purpose of reducing the side effects of using ACE inhibitors for the treatment of hypertension. ACE-inhibitory peptides have been found in several fermented products such as miso, nato, yogurt, cheese, etc. (Murray and Fitzgerald, 2007). This research was conducted to investigate the effect of the addition of palm sugar to functional properties such as the soluble protein, the degree of hydrolysis and ACE inhibitor activity of bekasam.

\section{Materials and methods}

\subsection{Materials}

The materials used in the study were oci fishes, palm sugar, rice and pepsin. The oci fishes were obtained from Gorontalo, Sulawesi Island while the palm sugar and rice were obtained from central Java area. Trypsin (porcine stomach mucosa) was purchased from Wako Pure Chemical Industry Ltd., Japan.

\subsection{Sample preparation}

The proximate analysis of the fresh oci fish was conducted. Bekasam of oci fish $(50 \mathrm{~g})$ was added with 100 $\mathrm{mL}$ aquadest and blended with a food processor (Panasonic) for 5 mins. The bekasam extract was then homogenized with a homogenizer for 10 mins. The bekasam extract was incubated into shaking water bath Taitec Personal- 11 for 30 mins at $70^{\circ} \mathrm{C}$, and then the extract was cooled at room temperature. 


\subsection{Hydrolysis protein by trypsin}

Bekasam extract was adjusted to $\mathrm{pH} 2.0$ with $1 \mathrm{M}$ of $\mathrm{HCl}$. Trypsin (porcine stomach mucosa) was added into the bekasam extract at an amount of $0.01 \mathrm{~g}$. After $2 \mathrm{hrs}$ of incubation at $37^{\circ} \mathrm{C}$ the hydrolysate $\mathrm{pH}$ was adjusted to 7.0 with $1 \mathrm{M}$ of $\mathrm{NaOH}$ and the hydrolysis by trypsin was terminated by heating at $95^{\circ} \mathrm{C}$ for 10 mins followed by cooling on ice (Salwanee et al., 2013).

\subsection{Degree of hydrolysis $(\mathrm{DH})$ analysis}

The degree of hydrolysis analysis is the percentage of solubilized protein in 20\% trichloroacetic acid (TCA), in relation to the total protein content of the sample. Aliquots of $500 \mu \mathrm{L}$ of the hydrolysed protein were mixed with $500 \mu \mathrm{L}$ of $20 \%$ TCA solution to obtain the soluble and insoluble fractions in 10\% TCA. After 30 mins of incubation at room temperature, the mixture was centrifuged at $3000 \mathrm{x} g$, and the soluble protein content of the supernatant was analysed spectrophotometrically using Lowry et al. (1951) method. Protein soluble concentration was obtained by comparing the absorbance of sample and the absorbance of bovine serum albumin (BSA). The degree of hydrolysis was counted following the equation:

$$
\text { DH }(\%)=\frac{\text { Soluble protein }}{\text { Total protein }} \times 100 \%
$$

\subsection{ACE-inhibitory activity}

ACE-inhibitory activity was determined following the method of Arihara et al. (2001). A sample solution of the synthetic peptide at the amount of $6 \mathrm{~mL}$ was mixed with $50 \mathrm{~mL}$ of $7.6 \mathrm{mM}$ HHL (hippuryl-His-Leu) containing $100 \mathrm{mM}$ borate buffer $(\mathrm{pH} 8.3)$ and $608 \mathrm{mM}$ $\mathrm{NaCl}$. Before reacting with $\mathrm{ACE}$, the sample was preincubated for 5 mins at $37^{\circ} \mathrm{C}$ in a water bath. The reaction was initiated by the addition of $20 \mathrm{~mL}$ of 60 $\mathrm{mU} / \mathrm{mL}$ ACE dissolved in borate buffer $(\mathrm{pH}$ 8.3) containing $200 \mathrm{mM}$ boric acid and $50 \mathrm{mM}$ sodium tetraborate. The mixture was incubated for $30 \mathrm{mins}$ at $37^{\circ}$ C. The reaction was stopped by adding $554 \mathrm{~mL}$ of $0.1 \mathrm{M}$ $\mathrm{HCl}$, except for the blank which had already added by $554 \mathrm{~mL}$ of $0.1 \mathrm{M} \mathrm{HCl}$ before the incubation. The product (hippuric acid) of the reaction was extracted by the addition of $1.5 \mathrm{~mL}$ of ethyl acetate and vigorous mixing. Then, the mixture was centrifuged at $2500 \mathrm{rpm}(1170 \mathrm{x}$ $g$ ) for 15 mins. A total of $1 \mathrm{~mL}$ of supernatant was collected into another tube and dried at $100^{\circ} \mathrm{C}$ for 10 mins. The tube was cooled at room temperature for 10 mins and then $1 \mathrm{~mL}$ of $1 \mathrm{M} \mathrm{NaCl}$ was added into it. It was stirred with a vortex mixer for $30 \mathrm{~s}$. The hippuric acid liberated by ACE was photometrically determined at 228 $\mathrm{nm}$. The ACE-inhibitory activity was calculated with the following formula:

$$
\text { Inhibition }(\%)=\frac{(E c-E s)}{(E c-E b)} \times 100 \%
$$

Where Ec is the control absorbance; $\mathrm{Eb}$ is the blank absorbance; and Es is the sample absorbance.

\section{Results and discussion}

The results of the proximate composition of oci fish are shown in Table 1. The average values for protein, fat, ash and carbohydrate were $65.00 \pm 1.20 \mathrm{~g} / 100 \mathrm{~g}$, $25.63 \pm 0.57 \mathrm{~g} / 100 \mathrm{~g}, 5.69 \pm 0.98 \mathrm{~g} / 100 \mathrm{~g}$ and $3.68 \pm 0.34$ g/100 g (in \% dry weight basis), respectively. Protein was the major component and this indicated that oci fish is a rich source of protein. The protein content of oci fish was similar to the protein content of tuna fish $(65.04 \pm 1.40 \mathrm{mg} / \mathrm{mL})$, but oci fish had a higher fat and ash content $(11.77 \pm 1.41(\% \mathrm{db})$ and $3.12 \pm 0.11(\% \mathrm{db}))$ (Salwanee et al., 2013).

Table 1. Proximate composition of oci fish (fresh)

\begin{tabular}{lc}
\hline \multicolumn{1}{c}{ Component } & Percentage $(\%) \mathrm{db})$ \\
\hline Ash & $5.69 \pm 0.98$ \\
Protein & $65.00 \pm 1.20$ \\
Lipids & $25.63 \pm 0.57$ \\
Carbohydrate (by difference) & $3.68 \pm 0.34$ \\
\hline
\end{tabular}

3.1 Effects of different palm sugar concentration on the soluble protein content of oci bekasam protein extract

Effects of concentration of palm sugar on the soluble protein content of oci bekasam protein extract, that was fermented for 8 days after hydrolysed by trypsin are tabulated in Table 2. The content of soluble protein in the oci bekasam protein extract before hydrolysis was 5 $\mathrm{mg} / \mathrm{ml}$. When the oci bekasam protein extract was hydrolysed by trypsin, the content of soluble protein increased and was significantly different $(p<0.05)$. The highest soluble protein of oci bekasam protein extract was obtained with the addition of palm sugar approximately at $10 \%(16.57 \%)$. On the other hand, the lowest soluble protein of oci bekasam protein extract was obtained with $30 \%$ addition of palm sugar $(10.85 \%)$. Higher soluble protein content obtained upon tryptic hydrolysis is probably due to trypsin's specificity, as it is known that trypsin preferentially catalyses polypeptides on the carboxyl side of basic amino acids (arginine or lysine). In this study, amino acid components analysed with LC-MS indicated that there was arginine dan lysine in the oci fish (data not shown). Food protein-derived bioactive peptides are naturally physiologically active peptide fragments encrypted within the sequence of food proteins and can be released through enzymatic hydrolysis and microbial fermentation. Enzymatic hydrolysis is a widely used method to release ACEinhibitory peptides from marine fish proteins. The 
effectiveness of using this method to generate specific peptide fragments with inhibitory activity mainly depends on the proteolytic enzyme used, hydrolysis conditions and the degree of hydrolysis (DH) achieved.

Table 2. Soluble protein content of extract of oci bekasam protein that was added with various concentration of palm sugar, fermentation by trypsin

\begin{tabular}{cc}
\hline Palm sugar (\%) & Soluble Protein content $(\mathrm{mg} / \mathrm{mL})$ \\
\hline 10 & $16.57 \pm 0.55$ \\
20 & $15.38 \pm 0.18$ \\
30 & $10.85 \pm 0.28$ \\
\hline
\end{tabular}

3.3 Degree of hydrolysis and ACE-inhibitory activity of hydrolysates of oci bekasam protein extracts added with different palm sugar concentration

Enzymatic hydrolysis was performed using trypsin. Hydrolysis efficiency was evaluated by measuring the degree of hydrolysis $(\mathrm{DH})$ in the hydrolysates that had been generated using three different palm sugar concentration (Table 3). Overall, the hydrolysis of the oci bekasam protein extracts was the highest rate of hydrolysis during the 8 hours fermentation. The rapid increase in DH indicated that a large amount of peptides were cleaved from oci bekasam protein extracts and released into hydrolysates at different palm sugar added concentration. These results inferred that the higher concentration palm sugar added, the less amount of oci bekasam protein hydrolyzed. The rate of enzymatic cleavage of peptide bonds is an important factor in determining the rate of DH (Benjakul and Morrissey, 1997). These peptides also act as effective substrate competitors to undigested or partially digested compact proteins in the substrate (Nguyen et al., 2011). Decreased hydrolysis reaction rate in oci bekasam protein extract can also be attributed to the limited availability of the substrate, as it is known that the substrate different in the palm sugar concentration.

Table 3. Degree of Hydrolysis of the extract of oci bekasam protein that was added with various concentration of palm sugar and fermented for 8 days

\begin{tabular}{cc}
\hline Palm sugar (\%) & Degree of Hydrolysis $(\% \mathrm{db})$ \\
\hline 10 & $21.33 \pm 0.31$ \\
20 & $19.73 \pm 0.50$ \\
30 & $15.27 \pm 0.42$ \\
\hline
\end{tabular}

Among the concentration of the added palm sugar, the hydrolysis activity on the oci bekasam protein extract with $10 \%$ added palm sugar showed the highest rate (21.33\%), followed by $20 \%$ added palm sugar (19.73\%). Whereas, the lower DH values was observed with the $30 \%$ palm sugar added (15.27\%). The efficiency of trypsin in catalysing the hydrolysis depends on the nature of the oci bekasam proteins extract. Lower DH value at $30 \%$ added palm sugar could probably due to the substrate specificity, as it was known that increasing the palm sugar concentration causes the protein component to decrease.

ACE-inhibitory activity of hydrolysate protein of oci bekasam is shown at Table 4. The ACE-inhibitory activity of protein oci bekasam that was added with $10 \%$, $20 \%$ and $30 \%$ palm sugar and fermented for 8 days were $87.39 \%, 84.52 \%$, and $77.68 \%$, respectively. Wikandari and Yuanita (2016) indicated that the ACE-inhibitory activity of bandeng bekasam protein extract that was hydrolysed by trypsin enzyme was $69.87 \%$. This indicated that hydrolysate of protein of oci bekasam hydrolyzated by trypsin has higher ACE-inhibitory activity than the extract of bandeng bekasam protein. So, hydrolysates of oci bekasam that was hydrolysed by trypsin had high potential as an ACE inhibitor. The ACE -inhibitory activity causes the peptides to be released by the protease digestion (trypsin). Korhomen and Pihlanto (2006) indicated that such peptides are inactive within the sequence of the parent protein and can be released in three ways: (1) through hydrolysis by digestive enzymes, (2) through the action of proteolytic enzymes derived from microorganisms or plants and (3) through hydrolysis by proteolytic microorganism. Jamhari et al. (2013) found that meat extract of Baliu cattle, Kacang goat, native chicken, and local duck after proteolytic reaction used protease can show ACE-inhibitory activity.

Table 4. ACE-inhibitory activity (\%) of hydrolysate protein of oci bekasam protein added with various concentration of palm sugar.

\begin{tabular}{cc}
\hline Palm sugar (\%) & ACE-inhibitory activity (\%) \\
\hline 10 & $87.39 \pm 0.01$ \\
20 & $84.52 \pm 0.07$ \\
30 & $77.68 \pm 0.63$ \\
\hline
\end{tabular}

To investigate the effects of palm sugar concentration on ACE-inhibitor activity, samples taken from the hydrolysates at different palm sugar concentrations were subjected to ACE-inhibitor activity assay at a concentration of $2 \mathrm{mg}$ peptide $/ \mathrm{mL}$ (Table 4). Among all hydrolysates, the ACE-inhibitor activity decreased with increasing palm sugar concentration. The ACE-inhibitor activity of hydrolysate of oci bekasam protein extract added with various concentration of palm sugar resulted in forming simpler peptides inhibiting ACE in the process of liberating hippuric acid from hyppuryl-L-hystidyl-L-leucine (HHL). The hydrolysis of oci bekasam protein extract by trypsin produced many peptides which played the role in inhibiting the ACE activity. ACE inhibitor activity of hydrolysate of oci bekasam was relatively high and thus, has a high potential as an antihypertensive agent. The highest ACE inhibition at a level of $87.39 \%$ was observed for the hydrolysates of oci bekasam protein extract that was 
added with $10 \%$ palm sugar. In particular, ACE-inhibitor activity significantly decreased if the concentration of palm sugar increased which is depicted as a fast decrease in $\mathrm{DH} . \mathrm{DH}$ is defined as the ratio of the fraction of peptide bonds cleaved to the total number of peptide bonds (Adler-Nissen, 1982), and it has been widely used to evaluate hydrolytic progress.

The positive correlation between DH value and ACE -inhibitory activity has been reported in studies on the proteolysis of canola meal (Wu et al., 2009), cuttlefish muscle (Balti et al., 2010), palm kernel cake (Zarei et al., 2015) and bovine collagen (Zhang et al., 2013) proteins. It has been suggested that reaching a certain level of $\mathrm{DH}$ may contribute to the release of more active peptides from protein precursors (Wu, 2009).

\section{Conclusion}

The result showed that the initial concentration of soluble protein of oci bekasam protein extract was $5.00 \pm 0.10 \mathrm{mg} / \mathrm{mL}$. After hydrolysis by trypsin, the soluble protein content increased to $16.57 \pm 0.55 \mathrm{mg} /$ $\mathrm{mL}, 15.38 \pm 0.18 \mathrm{mg} / \mathrm{mL}$ and $10.85 \pm 0.28 \mathrm{mg} / \mathrm{mL}$ for $10 \%, 20 \%$ and $30 \%$ added palm sugar respectively. The degree of hydrolysis was $21.33 \pm 0.31 \%, 19.73 \pm 0.50 \%$ and $15.27 \pm 0.42 \%$, respectively and ACE-inhibitory activity were $87.39 \pm 0.01 \%, 84.52 \pm 0.84 \%$, and $77.68 \pm 0.63 \%$, respectively. Based on the results, the best palm sugar concentration is $10 \%$, due to the higher soluble protein degree of hydrolysis and ACE-inhibitory activity.

\section{Conflict of Interest}

The authors declare no conflict of interest in the manuscript.

\section{Acknowledgment}

The authors wish to thank DIKTI INDONESIA by the grant of PDUPT 2018 134/UN1/DITLIT/DIT-LIT/ LT/2018 for supporting this project. The authors also acknowledge Dr. Keni Vidilaseris, University of Helsinki, Finlandia for careful reading of the manuscript.

\section{Reference}

Adler-Nissen, J. (1982). Limited enzymic degradation of proteins: A new approach in the industrial application of hydrolases. Journal of Chemical Technology and Biotechnology, 32(1), 138-156. https://doi.org/10.1002/jctb.5030320118

Ambigaipalan, P., Al-Khalifa, A.S. and Shahidi, F. (2015). Antioxidant and angiotensin I converting enzyme (ACE) inhibitory activities of date seed protein hydrolysates prepared using Alcalase,
Flavourzyme and Thermolysin. Journal of Functional Foods, 18(Part B), 1125-1137. https:// doi.org/10.1016/j.jff.2015.01.021

Arihara, K., Nakashima, Y., Mukai, T., Ishikawa, S. and Itoh, M. (2001). Peptide inhibitor for Angiotennsin -I Converting Enzyme From Enzymatic Hydrolisates of Protein Skeletal Muscle Protein. Meat Science, 57 (3), 319-325. https://doi.org/10.1016/S0309-1740 (00)00108-X

Astawan, M., Wahyuni, M., Yasuhara, T., Yamada, K., Tadokoro, T. and Maekawa, A. (1995). Effects of Angiotensin I-Converting Enzyme Inhibitory Substances Derived from Indonesian Dried-Salted Fish on Blood Pressure of Rats. Bioscience, Biotechnology, and Biochemistry, 59(3), 425-429. https://doi.org/10.1271/bbb.59.425

Balti, R., Nedjar-Arroume, N., Adje, E.Y., Guillochon, D. and Nasri, M. (2010). Analysis of novel angiotensin I-converting enzyme inhibitory peptides from enzymatic hydrolysates of cuttlefish (Sepia officinalis) muscle proteins. Journal of Agricultural and Food Chemistry, 58(6), 3840-3846. https:// doi.org/10.1021/jf904300q

Benjakul, S. and Morrissey, M.T. (1997). Protein hydrolysates from pacific whiting solid wastes. $J$. Agric. Food Chem., 45, 3423-3430. https:// doi.org/10.1021/jf970294g

Chiang, W.-D., Tsou, M.-J., Tsai, Z.-Y. and Tsai, T.-C. (2006). Angiotensin I-Converting Enzyme Inhibitor derived from soy protein hydrolysate and produced by using membrane reactor. Food Chemistry, 98(4), $725-732$.

https://doi.org/10.1016/

j.foodchem.2005.06.038

Fernández, M., Benito, M.J., Martín, A., Casquete, R., Córdoba, J.J. and Córdoba, M.G. (2016). Influence of starter culture and a protease on the generation of ACE-Inhibitory and antioxidant bioactive nitrogen compounds in Iberian Dry-Fermented sausage "salchichon". Heliyon, 2(3), e00093. https:// doi.org/10.1016/j.heliyon.2016.e00093

García-Tejedor, A., Sánchez-Rivera, L., Castelló-Ruiz, M., Recio, I., Salom, J.B. and Manzanares, P. (2014). Novel Antihypertensive Lactoferrin-Derived Peptides Produced by Kluyveromyces marxianus: Gastrointestinal Stability Profile and in Vivo Angiotensin I-Converting Enzyme (ACE) Inhibition. Journal of Agricultural and Food Chemistry, 62(7), 1609-1616. https://doi.org/10.1021/jf4053868

Bakris, G., Sarafidis, P., Agarwal, R. and Ruilope, L. (2014). Review of blood pressure control rates and outcomes. Journal of the American Society of Hypertension, 8(2), 127-141. https:// 
doi.org/10.1016/j.jash.2013.07.009

Guang, C. and Phillips, R.D. (2009). Plant Food-Derived Angiotensin I Converting Enzyme Inhibitory Peptides. Journal of Agricultural and Food Chemistry, 57(12), 5113-5120. https:// doi.org/10.1021/jf900494d

$\mathrm{Gu}, \mathrm{Y}$. and $\mathrm{Wu}$, J. (2013). LC-MS/MS Coupled with QSAR Modeling in Characterising of Angiotensin IConverting Enzyme Inhibitory Peptides from Soybean Proteins. Food Chemistry, 141(3), 26822690.

https://doi.org/10.1016/

j.foodchem.2013.04.064

Hang, M. and Zhao, X.-H. (2012). Fermentation Time and Ethanol/water-Based Solvent System Impacted in Vitro ACE-Inhibitory Activity of the Extract of Mao-Tofu Fermented by Mucor Spp. CyTA-Journal of Food, 10(2), 137-143. https:// doi.org/10.1080/19476337.2011.601428

Hayes, M., Stanton, C., Fitzgerald, G.F. and Ross, R.P. (2007). Putting Microbes to Work: Diary Fermentation, Cell Factories and Bioactive Peptides. Part II: Bioactive Peptide Functions. Biotechnology Journal, 2(4), 435-449. https://doi.org/10.1002/ biot. 200700045

Hernandez-Ledesma, B., Del Mar Contreras, M. and Recio, I. (2011). Antihypertensive Peptides: Production, Bioavailability and Incorporation into Foods. Advances in Colloid and Interface Science, 165(1), 23-35. https://doi.org/10.1016/ j.cis.2010.11.001

Iwaniak, A., Minkiewicz, P. and Darewicz, M. (2014). Food-Originating ACE Inhibitors, Including Antihypertensive Peptides, as Preventive Food Components in Blood Pressure Reduction. Comprehensive Reviews in Food Science and Food Safety, 13(2), 114-134. https://doi.org/10.1111/1541 $-4337.12051$

Jakubczyk, A., Karas, M., Baraniak, B. and Pietrzak, M. (2013). The Impact of Fermentation and in Vitro Digestion on Formation Angiotensin Converting Enzyme (ACE) Inhibitory Peptides from Pea Proteins. Food Chemistry, 141(4), 3774-3780. https://doi.org/10.1016/j.foodchem.2013.06.095

Jamhari,L., Yusiati, M., Suryanto, E., Cahyanto, M.N., Erwanto, Y. and Muguruma, M. (2013). Comparative study on angiotensin converting enzyme inhibitory activity of hydrolysate of meat protein of indonesian local live stocks. Journal of the Indonesian Tropical Animal Agriculture, 38(1), 27-33. https:// doi.org/10.14710/jitaa.38.1.27-33

Jimsheena, V.K. and Gowda, L.R. (2011). Angiotensin I -Converting Enzyme (ACE) Inhibitory Peptides
Derived from Arachin by Simulated Gastric Digestion. Food Chemistry, 125(2), 561-569. https://doi.org/10.1016/j.foodchem.2010.09.048

Kim, Y.K., Yoon, S., Yu, D.Y., Lönnerdal, B. and Chung, B.H. (1999). Novel Angiotensin-IConverting Enzyme Inhibitory Peptides Derived from Recombinant Human $\alpha(\mathrm{s} 1)$-Casein Expressed in Escherichia Coli. Journal of Dairy Research, 66 (3), 431-439. https://doi.org/10.1017/ S0022029999003556

Korhonen, H. and Pihlanto, A. (2006). Bioactive peptide: Production and functionality. International Dairy Journal, 16(9), 945-869. https://doi.org/10.1016/ j.idairyj.2005.10.012

Lackland, D.T. and Weber, M.A. (2015). Global burden of cardiovascular disease and stroke: Hypertension at the core. Canadian Journal of Cardiology, 31(5), 569-571. https://doi.org/10.1016/j.cjca.2015.01.009

Lee, B.H., Lai, Y.S. and Wu, S.C. (2015). Antioxidation, Angiotensin Converting Enzyme Inhibition Activity, Nattokinase, and Antihypertension of Bacillus Subtilis (Natto)-Fermented Pigeon Pea. Journal of Food and Drug Analysis, 23(4), 750-757. https:// doi.org/10.1016/j.jfda.2015.06.008

Liepke, C., Zucht, H.D., Forssmann, W.G. and Standker, L. (2001). Purification of novel peptide antibiotics from human milk. Journal of Chromatography B: Biomedical Sciences and Applications, 752(2), 369377. https://doi.org/10.1016/S0378-4347(00)00516-8

Lowry, O.H., Rosebrough, N.J., Farr, A.L. and Randal, R.J. (1951). Protein Measurement with the Folin Phenol Reagent. The Journal of Biological Chemistry, 193(1), 265-275

Maestri, E., Marmiroli, M. and Marmiroli, N. (2015). Bioactive Peptides in Plant-Derived Foodstuffs. Journal of Proteomics, 147, 140-155. https:// doi.org/10.1016/j.jprot.2016.03.048

Majumder, K. and Wu, J. (2010). A New Approach for Identification of Novel Antihypertensive Peptides from Egg Proteins by QSAR and Bioinformatics. Food Research International, 43(5), 1371-1378. https://doi.org/10.1016/j.foodres.2010.04.027

Moayedi, A., Mora, L., Aristoy, M.C., Hashemi, M., Safari, M. and Toldrá, F. (2016). ACE-Inhibitory and Antioxidant Activities of Peptide Fragments Obtained from Tomato Processing By-Products Fermented Using Bacillus Subtilis: Effect of Amino Acid Composition and Peptides Molecular Mass Distribution. Applied Biochemistry and Biotechnology, 181(1), 48-64. https:// doi.org/10.1007/s12010-016-2198-1

Murray, B.A. and Fitzgerald, R.J. (2007). Angiotensin 
converting enzyme inhibitory peptides derived from food proteins: biochemistry bioactivity and production. Current Pharmaceutical Design, 13(8), 773-791.

doi.org/10.2174/138161207780363068

Nejati, F., Rizzello, C.G., Di Cagno, R., SheikhZeinoddin, M., Diviccaro, A., Minervini, F. and Gobbetti, M. (2013). Manufacture of a Functional Fermented Milk Enriched of Angiotensin-I Converting Enzyme (ACE)-Inhibitory Peptides and $\gamma$ -Amino Butyric Acid (GABA). LWT-Food Science and Technology, 51(1), 183-189. https:// doi.org/10.1016/j.lwt.2012.09.017

Nguyen, H.T.M., Sylla, K.S.B., Randriamahatody, Z., Donnay-Moreno, C., Moreau, J., Tran, L.T. and Bergé, J.P. (2011). Enzymatic hydrolysis of yellowfin tuna (Thunnus albacares) by-products using protamex protease. Food Technol. Biotechnol. $49,48-55$.

Ondetti, M., Rubin, B. and Cushman, D.W. (1977). Design of specific inhibitors of angiotensinconverting enzyme: new class of orally active antihypertensive agents. Science, 196(4288), 441444. https://doi.org/10.1126/science.191908

Poulter, N.R., Prabhakaran, D. and Caulfield, M. (2015). Hypertension. The Lancet, 386(9995), 730-731. https://doi.org/10.1016/S0140-6736(14)61468-9

Rizzello, C.G., Cassone, A., Di Cagno, R. and Gobbetti, M. (2008). Synthesis of Angiotensin I-Converting Enzyme (ACE)-Inhibitory Peptides and gammaAminobutyric Acid (GABA) during Sourdough Fermentation by Selected Lactic Acid Bacteria. Journal of Agricultural and Food Chemistry, 56(16), 6936-6943. https://doi.org/10.1021/jf800512u

Salwanee, S., Aida, W.M.M., Mamot, M.Y. and Ibrahim, S. (2013). Effects of enzyme concentration, temperature, $\mathrm{pH}$, znd time on the Degree of Hydrolysis of Protein Extract from Viscera of Tuna (Eutheynnus) by using alcalase. Sains Malay. 43(3), 279-287.

Sornwatana, T., Bangphoomi, K., Roytrakul, S., Wetprasit, N., Choowongkomon, K. and Ratanapo, S. (2015). Chebulin: Terminalia Chebula Retz. FruitDerived Peptide with Angiotensin-I-Converting Enzyme Inhibitory Activity. Biotechnology and Applied Biochemistry, 62(6), 746-753. https:// doi.org/10.1002/bab.1321

Shu, G., Yang, H., Chen, H., Zhang, Q. and Tian, Y. (2015). Effect of Incubation Time, Inoculum Size, Temperature, Pasteurization Time, Goat Milk Powder and Whey Powder on ACE-inhibitory Activity in Fermented Milk by L. Plantarum LP69. Acta Sci. Pol. Technol. Aliment. 14, 107-116.
Thewissen, B.G., Pauly, A., Celus, I., Brijs, K. and Delcour, J.A. (2011). Inhibition of Angiotensin IConverting Enzyme by Wheat Gliadin Hydrolysates. Food Chemistry, 127(4), 1653-1658. https:// doi.org/10.1016/j.foodchem.2010.11.171

van der Ven, C., Gruppen, H., de Bont, D.B.A. and Voragen, A.G.J. (2002). Optimisation of the Angiotensin Converting Enzyme Inhibition by Whey Protein Hydrolysates Using Response Surface Methodology. International Dairy Journal, 12(10), 813-820. https://doi.org/10.1016/S0958-6946(02) 00077-8

Vermeirssen, V., Van Camp, J., Decroos, K., Van Wijmelbeke, L. and Verstraete, W. (2003). The Impact of Fermentation and In Vitro Digestion on the Formation of Angiotensin-I-Converting Enzyme Inhibitory Activity from Pea and Whey Protein. Journal of Dairy Science, 86(2), 429-438. https:// doi.org/10.3168/jds.S0022-0302(03)73621-2

Wang, D., Wang, L.J., Zhu, F.X., Zhu, J.Y., Chen, X.D., Zou, L., Saito, M. and Li, L.T. (2008). In Vitro and in Vivo Studies on the Antioxidant Activities of the Aqueous Extracts of Douchi (A Traditional Chinese Salt-Fermented Soybean Food). Food Chemistry, 107(4), 1421-1428. https://doi.org/10.1016/ j.foodchem.2007.09.072

Wikandari, P.R. and Yuanita, L. (2016). Pengaruh degradasi enzim proteolitik terhadap aktivitas angiotensin converting enzyme inhibitor bekasam dengan Lactobacillus plantarum B 1765. Agritech, 36(2), 170-175. https://doi.org/10.22146/ agritech.12861

Wu, J.P., Aluko, R.E. and Muir, A.D. (2009). Production of angiotensin I-converting enzyme inhibitory peptides from defatted canola meal. Bioresource Technology, 100(21), 5283-5287. https:// doi.org/10.1016/j.biortech.2009.03.090

Zarei, M., Forghani, B., Ebrahimpour, A., Abdul-Hamid, A., Anwar, F. and Saari N. (2015). In vitro and in vivo antihypertensive activity of palm kernel cake protein hydrolysates: Sequencing and characterization of potent bioactive peptides. Industrial Crops and Products, 76, 112-120. https:// doi.org/10.1016/j.indcrop.2015.06.040

Zhang, Y., Olsen, K., Grossi, A. and Otte, J. (2013). Effect of pretreatment on enzymatic hydrolysis of bovine collagen and formation of ACE-inhibitory peptides. Food Chemistry, 141(3), 2343-2354. https://doi.org/10.1016/j.foodchem.2013.05.058 